\title{
THE CHARACTERIZATION OF LORD VOLDEMORT IN NOVEL HARRY POTTER AND THE HALF-BLOOD PRINCE BY J.K ROWLING SEEN FROM PSYCHOANALYSIS
}

\author{
Nurul Fitri \\ SMA Muhammadiyah 10, Surabaya, nurulfitri89@yahoo.com
}

\begin{abstract}
The science of psychoanalysis not only uses to reveal the behaviour of human, but it can be used also to analyze the literary works. This study concerns analyzing one of character in J.K Rowling's novel Harry Potter and the Half-Blood Prince "Lord Voldemort" by using psychoalaysis approach. This study focuses on the relation characterization of Voldemort between his past event. The goal of this study is to find out the the character and characterization of Voldemort relate to Voldemort's life seen psychoanalysis.Utilizing the descriptive qualitative as method the results of this study are the character that is depicted in Voldemort is antagonist and static character, the development of Voldemort's characterization is found in four steps: Voldemort's childhood, adolescence, Tom Riddle after Hogwarts, and Tom Riddle transforms being Lord Voldemort. The id is a part of unconscious, likely influence the personality of Voldemort and every action that he takes. It causes he grow up to be a scary and horrible person and he also does a lot of vile actions to satisfy his desire and to avoid feeling anxiety and uncomfotable. Like, he feels anxious because he can die, so, to avoid his feeling he creates horcrux to beat the death.
\end{abstract}

Keywords: character, characterization, psychoanalysis, Lord Voldemort.

Essentially, the most difficult creature to understand is a human because they always have secret in their lives. As usual, they will keep and not allow other people to know their problems because they feel that it is not important to share their problems. Furthermore, they are shy to share it. Regarding of the impact because they cannot express their problems, they become quieter, grumpier, do something strangely, and can change their behavior in the future. Based on that case, the theory that deals with human being is psychology. It is a theory which attempts to examine the problem faced by human. Atkinson that psychology is a science that observes and learns about human behavior (Minderope, 2011:3).

This theory is developed by psychiatry named Sigmund Freud (1856-1939). He states that psychology is a science which can explain about the psyche structure and personality of human. By developing it, psychology can be associated to other knowledge. One of them is literature. The relationship between psychology and literature is the literary works which reflects psyche, condition, and personality of human which is created by making story. Thus, the literary works can be analyzed by using psychology perspective.

Literary work is a unique art work and it also has beauty. It can be seen in several aspects, which are the style of language, choice of words, the problem in the story, the character in the story and others. Minderop conves that the experts thought literary work is a work that uses a beautiful language and has different language from other works (2011:73). Because of those things, the literary work attracts many people to read and feel curious to read and know more about the story behind the creation of those. Therefore, it makes literary work is able to be analyzed by using psychology perspective.

Novel is one example of literary work that can be analyzed by using psychoanalysis perspective. It has two aspect that builds story whic is intrinsic and extrinsic. According to Kennedy (1983:89) novel is a product of literary work that contains two aspect intrinsic and extrinsic (plot, setting, character, conflict, personality, point of view and others) (Hasmiati, 2012:2). Those elements can be seen and analyzed in many perspectives, especially psychoanalysis. 
Harry Potter and the Half-Blood Prince is one example of novel, this series tells us about dark wizard "Lord Voldemort" who has secreat life that influences his character in life. It also tells us about the nasty action of Voldemort such as, he did several murders, he wanted to take control the magic world by destroying the wizards who did not support him and demolishing muggle (people who do not have power of magic) and he was assisted by follower "Death Eaters" for his plans.

Based on the story above, the significant thing in this novel was everything that Voldemort did deal with his past. His experience about his past was bad, his mother died when he was still baby, of course he lacked of affection, when he lived in orphanage he had not friends so he always made something bad. Therefore the writer is eager to analyze this novel because it has psychoanalysis perspective in Voldemort. Based on the background above, the writer formulates three questions as follow:

1. What is the character of Voldemort potrayed in Harry Potter and the Half-Blood Prince?

2. What is the Voldemort characterization depicted in Harry Potter and the Half-Blood Prince?

3. How do the characterization relate to Voldemort's life seen from psychoanalysis approach?

\section{Review of Related Literature}

Generally, a literary work especially fiction (novel) has elements to develop the story. One of them is character. Character is one of the essential things in a novel. The story will be useless if it does not have character inside even though the story has a good setting, plot, and theme. Following Potter explains that character is a basic element in imaginative literature (1967:1). Kennedy and Gioia state that character is a person who lives in a story (2007:73). Same as in the previous theory, Abrams also adds that it is a person represented in narrative work who sketches in a particular type (1999:32).

Furthermore character is also classified into several types; the character based on the role and based on the development. Here, the kinds of character based on role; protagonist is the essential character of the story. Like Potter says that protagonist is always the focal point of a story and forefront of the action (1967:7). Actually, a protagonist is faced with conflict that must be resolved. Robert and Jacobs (1986:136) state that it is the central to do action and against an antagonist (Elyla, 2010:8). According to Potter, antagonist is a person that opposes the protagonist (1967:7). Robert and Jacobs (1986:139) says that antagonist is a character who opposes the protagonist and causes of the problem on particular situation (Elyla, 2010: 9).

As Potter says that to describe the nature of the character, it deals with the concept of characterization. It is the process or method by which the author uses to reveal or describe the character personality in a story. He also mentions that a number of methods of characterization to reveal the person's character by what he says and does his speech, and his physical appearance (1967:3-4).

Psychology theory focuses on human personality because personality of someone can influence behavior and the way of thinking of human in society. Another reason is human personality made by someone's experience. Minderop says that personality created by experience of someone. So, it can influence someone's behavior in society (2011:4). He also adds there are several factors that give effect for developing human personality; past historical factor, contemporary factor, innate factor, and environment factor (2011:20).

Talking about unconscious mind, it influences human personality and behavior because people have secret life and they consider keeping their secret in unconscious. The 
unconscious mind is a place to save feeling, thought, pain, and memory. Most of the contents in unconscious are the unpleasant feeling, such as pain, anxiety, and conflict. Eagleton (1996:437) says, Freud believes that human's mind is influenced by unconscious mind because human personality is developed by human experience. He also describes human's mind likes iceberg which contains the secret of human, conflict, and several problems. So, he thinks that unconscious mind is the key to understand human personality. In addition, Minderop says that human behavior is often influenced by the unconscious trying to bring ourselves and behave without conscious (2011:13).

\section{The Structure of Human Personality}

The Id is part of human's personality and the place in unconscious. The basic work of id is satisfying the urges, needs, and desire. The id is like the king that all the id needs must be fulfilled. Freud adds that the id is pulsi reservoir and a source of psychic energy. Id as psychic energy that force human to fullfill the basic need, like eat, sexs, and reject the pain or uncomfortable (Minderop, 2011:21). The ego locates between between the conscious and unconscious. The working of the ego is trying to fulfill the pleasure of human but he is limited by reality. The Ego likes prime minister that has job to finish the problem that has relation with reality and he also fulfill the plasure of human (Minderop, 2011:21). The superego is the third system of human psyche, it is the moral system. Becaus it is a moral system, the superego has role as it takes control the authority of moral in personality, it reflects the moral action than the real action, it fights for the prefection than pleasure, and the superego as judge to judgment whether the action taken is right or wrong (Fudyartanta, 2012:141).

\section{The Development of Oral Phase}

This phase takes place during infacy and childhood in the first year. At this stage, the child is totaly dependent on the mother because the child needs food from mother. The mother duty at this phase is gives the food for the child through breastfeeding. According to Freud, he says that oral phase is the phase of babyhood and childhood in first year which the role of mother is important. On that phase mother has duty to feed by breastfeeding. In that process, the bound between mother and child is built. The child feels safe, comfort, and dependence on his mother (Fudyartanta, 2012:164).

\section{Anxiety}

Every situation that makes people worry and feeling threatened, it causes the people have the feeling of anxiety. It is because they have problem that is an obstacle to gain their purpose to achieve something. Following Minderop, she states that several conflicts and problems can obstruct the progress of individuals to achieve goals and it is one the source of anxiety. She also says that the threatened can be physic, psyche, and some unconfort feeling that causes anxiety (2011:28).

\section{Hatred}

Feeling hatred has relationship with feeling angry and jelousy. When people feeling hatred of something or someone, they have desire to abolish the source of feeling hatred. According to Krech (1974:479) hate has relationship with angry and the trait that marks felling of hatred is emerge the desire to kill or destroy the source of hatred. He also adds that someone always has feeling hatred and he or she will feel satisfied if the object of hatred is destroyed (Minderop, 2011:44).

\section{Research Method}


The writer uses qualitative method for defining the data of the research clearly. By the qualitative method that is made by the researcher, it is hoped the writer will be able to analyze the data and get the purpose of this thesis. It means that the research analyzes data by describing in detail not in the forms of numbers (or numeric) but they are in the forms of words, phrases, or utterances or sentences. Strauss emphasizes that qualitative method is a research that result of the data is not obtained by using statistical or measurement procedure (2007:11). Addition Miles and Huberman explain that data from qualitative research is the forms of words than numbers, the sources of it from an evironment and it also can help to understand the phenomena chronologically (1992:1-2).

\section{Source of Data}

In general, the data is taken and selected from the novel Harry Potter and the HalfBlood Prince by J.K Rowling that was published on July 15 2005. The data of the research focoses on analyzing Lord Voldemort

\section{Data Analysis Technique}

Data from this research analyses, sorts, categorizes and processes based on theoretical framework. There are some steps that will be applied to analyze Voldemort character. The procedures of the data analysis are: reading and comprehending the novel Harry Potter and the Half-Blood Prince by J.K Rowling., reading and comprehending the character of Voldemort, analyzing the character of Voldemort by using theory of character, analyzing the characterization of Voldemort by using theory of characterization, find out and analyze the characterization of Voldemort by using Psychoanalysis approach, and last, the writer summarize based on the discussion.

\section{Analysis \\ Antagonist and Static \\ Anatgonist}

Voldemort is one of the characters who plays role in the novel Harry Potter by J.K Rowling. He is described as figure that has bad character and personality. His action makes him as bad character. He always does anything that makes people suffer and pain, for instance, he makes people afraid of him by killing and giving terror. In addition, Voldemort is a person who dislikes Harry Potter and he always tries to hamper and murders him. He also causes a lot of mess and problem in particular situation. Because of his action and attitude, Voldemort is categorized as antagonist character.

In Harry Potter and the Half-Blood Prince, Voldemort is known as person who likes killing people. He killed people for they are against of him and he needed to kill them for his benefit. For example he killed Amelia Bones, it is proved by statement of the person who works in Ministry of Magic Cornelius Fudge:

"Amelia Bones. Head of the Department of Magical Law Enforcement. We think He-Who-Must-Not-Be-Named may have murdered her in person, because she was a very gifted witch and - and all the evidence was that she put up a real fight. '(HP6, 2005:1:13)

Looking at this incident, it can be said that Voldemort killed Amelia Bones because she tried to hamper and offend Voldemort. Thus, he decided murdering Amelia Bones because he disliked the effort of Amelia Bones that try to againts him. Other example describes Voldemort as killer when he studied in Hogwarts and killed a girl who studied in there. 

seven years at Hogwarts were marked by a number of nasty incidents to which they were never satisfactorily linked, the most serious of which was, of course, the opening of the Chamber of Secrets, which resulted in the death of a girl. As you know, Hagrid was wrongly accused of that crime." (HP6, 2005:17:362)

\section{Static}

Lord Voldemort is categorized as static character because at the beginning until the end he is consistence being cruel character. Especially in Harry Potter and the Half-Blood prince, Voldemort had been doing a lot of offense when he was a boy and he continued when he grows up. The first offense he did when he was a boy, he killed a rabbit of his friend in orphanage after he had argued with his friend. Then, when summer outing he asked his two friends to follow him enter the cave. After that, after that his two friends never same again, they became different. It is impossible if there no something happened that time. Not only that things happened when he was a boy, but he did offense when he studied in Hogwarts. This incident happened when Riddle opened the Chamber of Secret in Hogwarts and he needed victim to be sacrificed, so he choose the girl and killed her.

\section{Characterization of Lord Voldemort}

Actually, Voldermort's real name was Tom Marvolo Riddle. This name was given by his mother before she died. But right after he declared himself as a dark wizard, he changed his name into Lord Voldermort. Understanding characterization of Voldemort can be looked from his experience when he was a boy until he transforms "Dark Lord. By looking at his experience from Dumbledore's memory, the writer finds several points that show he is a weird boy and he behaves poorly.

When Voldemort was a boy he lived in orphanage because his mother died and his fathet left him. Losing his parents, he did not know who his parent was and lived in the orphanage was the basic reason of Riddle grew into an odd boy and behaved poorly. Mrs. Cole who ran the orphanage gave explanation about the behavior of Riddle.

"He scares the other children."

"You mean he is a bully?" asked Dumbledore.

"I think he must be," said Mrs. Cole, frowning slightly, "but it's very hard to catch him at it. There have been incidents. . . Nasty things" (.....)

"Billy Stubbs's rabbit. . . well, Tom said he didn't do it and I don't see how he could have done, but even so, it didn't hang itself from the rafters, did it?"

........... All I know is he and Billy had argued the day before. (HP6, 2005:13:267-268)

The dialogue between Mrs. Cole and Dumbledore tells the behavior of Riddle who is always scared children in orphanage by doing the worst thing and possibility he did bulling, unfortunately what Riddle did is difficult to catch him at it. It is supported by his action he killed Billy Stubbs's rabbit, but he did not admit that he was guilty. The other hand, Mrs. Cole said that Riddle and Billy had argued the day before. Riddle got angry and he disliked what Billy said or did so he decided to kill Billy's rabbit to vent his anger.

After he murdered and grabbed the two treasures of Hepzibah Smith, Riddle disappeared for a very long time and there's nobody knew about his. But when he was back, he was not Tom Riddle anymore but Lord Voldemort, "They do not call me 'Tom' anymore," he said. "These days, I am known as -" (HP6, 2005:20:442). He chose Voldemort as his name because it reflected himself as a dark wizard. The name of Voldermort is derived from 
French, Voluer means steal and mort means dead, so Voldermort means the man who steals the death. (Colbert, 2006: 205). Tom Riddle was not an innocent boy but he transformed being an evil figure. He had desire to control people and the world by killing and torturing them. He created himself as the dreaded wizard by making terror anywhere. He killed a lot of people to satisfy his desire and for him killing is an amusement thing. For example, he created horcrux (the place for soul to hide that makes someone immortal) because he wanted to be immortal so there's nobody can defeat him and to make it he had to kill people and he got that information from his teacher Prof. Slughron:

"By an act of evil - the supreme act of evil. By committing murder. Killing rips

the soul apart. The wizard intent upon creating a Horcrux would use the damage to his advantage: He would encase the torn portion — " (HP6, 2005:23:498)

\section{The Characterization of Lord Voldemort Seen from Psychoanalysis}

The development characterization of Voldemort is influenced by his past especially his childhood. In this section, the writer analyzes the hidden memory of Voldemort about his childhood that influences his character. Freud conveys that the behavior of human is more influenced by unconscious mind than conscious mind. Unconscious mind is filled by someone's painful memories and he tries to keep and hide them. From that situation, it can influence someone attitude and behavior or character (Minderop, 2011:13). In Riddle's case he has painful memories about his father. His father was a muggle (non-wizard) and left his mom when she was pregnant Riddle. Knowing the truth about his father, he hides and keeps it just for himself. But, the truth of his family he could deny so he did nasty thing by murdering his father and his father family. He killed them because he wanted to conceal the truth and kept his secret about his family history that he was son of a muggle. According to Krech (1974:479) hate has relationship with angry and the trait that marks felling of hatred is emerge the desire to kill or destroy the source of hatred (Minderop, 2011:44). Felling hatred makes Riddle murders his father and his father's family.

As long as Riddle kept his secret, he transformed being a man who had anger and hatred about something that has connection with muggle. Eagleton (1996:437) mentions Freud says that human's mind is influenced by unconscious mind because human personality is developed by human experience (Minderop, 2011:13). Riddle's life was always influenced by his past, so he tried to abolish something about muggle. For example, when he studied in Hogwarts there was incident happened when Riddle opened the Chamber of Secret in Hogwarts and he need victim to be sacrificed, so he chose the girl and killed her (HP6, 2005:17:362). The fact that the girl who killed by Voldemort is a Half-Blood likes him. He chose that girl besides he wanted to scarify her and she reminded Riddle about his family status that he was Half-Blood too. Riddle could not forget about his status that he is HalfBlood, so he did it. According to Freud that act of someone was usually influenced by his unconscious mind that tries to show up himself and what he does something without realize (Minderop, 2011:13). What Riddle has done is influenced by his past about his blood status and he cannot forget it. Riddle's memory hides in his unconscious mind and someday it can show up again.

Hiding and keeping his status, Riddle connects his blood status with famous ancestor, Salazar Slytherin who one of the persons builds Hogwarts by his ability. Riddle can speak parseltongue (persons with the ability to speak to snakes) like the ancestor Salazar Slytherin and makes him excited about the fact "How soon Riddle learned that the famous founder of the House could talk to snakes, (.....)The knowledge can only have excited him and increased his sense of self-importance (HP6, 2005:17:360). Riddle made Slytherin as his parents and 
rejected his biological parents by changing his name from Tom Riddle into Lord Voldemort because Tom is the name of his father and he really hated his father, thus he did not to use that name again. He considered himself as pure-blood and made himself as hero figure that splited the pure-blood from the half-blood and muggle. It proves that Riddle really does not want his status and wants to forget it by creating himself as pure-blood.

Following the explanation above it, describes that the characterization of Voldemort is affected by his unconscious mind. The unconscious mind itself is the place of the memory, traumatic events, and emotional events of someone. According to Minderop that unconscious mind is filled by someone's painful memories and he tries to keep and hide them (Minderop, 2011:13). In Voldemort's case he conceals his secret memory in it. On the other hand, unconscious mind is the place of the id, as Freud says that the id is located at unconscious mind. The id itself is the part of human personality that has characteristics like boss, it has to honor, masterful, and the desire of the id must be fulfilled. As Freud mentions the way of Id's works has relation with the principle of pleasure, it means it always seek the pleasure and avoids feeling discomfort (Minderop, 201121 ). Looking at Voldemort's case about his past that he never got what he needs in his past, so he has ambition to satisfy himself by fulfilling his needs, such as he wants to be the one who has power, immortal, and he has desire to be number one from the others. What Voldemort needs in line with the principle of the id.

Moreover, the id as structure of human personality, there is ego is a structure of it too. The ego is like the Prime Minister who has duty to fulfill what the Id needs. But, the ego works by the way satisfy the id by considering there is no trouble when the ego tries to fulfill what the id needs (Minderop, 2011:22). Beside, that the superego is the third system of human psyche, it is the moral system. Becaus it is a moral system, the superego has role as it takes control the authority of moral in personality. It is as judge to judgment whether the action taken is right or wrong (Fudyartanta, 2012:141).

In the case of Voldemort, the ego cannot fulfill the pleasure principle of the id because superego agganist the desire of id. It means what Voldemort needs are failed to be fulfilled. The result of that problem makes Voldemort feeling anxiety and uncomfortable always appear. In order to eliminate feeling anxiety and uncomfortable, he did the actions to satisfy his desire. For instance, he killed his father because he knew that his father left his mother and the truth that his father was a muggle. He was angry with his father and not comfort about his father status because he had desire to be the wizard who had pure-blood. He was worry if there was wizard knew about the fact of his statuse especially the wizards who followed him as the part of Death Eater. To satisfy his desire, he connected his status with the famous ancestor, Salazar Slytherin because he had same ability with him (can speak with sneak) and made himself as descent of him. The other examples showed the action of Voldemort that is influenced by id are he killed Hepzibah Smith, tried to ablish Harry Potter, and created horcruxes. Therefore, the id likely influences the personality of Voldemort and every action that he takes, it causes he grows up to be a scary man and horrible person and he also does a lot of vile actions to satisfy his desire and to avoid feeling of anxiety and uncomfortable.

\section{Conclusion}

After the writer analyzed this issue, there are several conclusions that found by the writer. First, Voldemort in novel Harry Potter and the Half Blood-Prince is categorized as antagonist character because he has nasty action and weird attitude. He is also categorized as static character because at the beginning until the end, he is consistence to do nasty action. 
Second, knowing the development of character of Voldemort, the writer analyzed the characterization of Voldemort by dividing the life of him into four time: childhood, adolscence, Tom Riddle after Hogwarts, and Tom Riddle transforms being Lord Voldemort. Following that analysis, Voldemort has odd attitude, he is killer, he wants a power and every action that he has done always has bad impact for people.

Third, the writer analyzed the characterization of Voldemort based on psychoanalysis approach. The characterization of Voldemort is affected by his unconscious mind. In Voldemort's case he conceals his secret memory in it. Unconscious mind is the place of the id. Looking at Voldemort's case about his past that he never gets what he needs in his past so he has ambition to satisfy himself by fulfilling his needs, such as he wanted to be the one who had power, immortal, and he has desire to be number one from the others. What Voldemort needed in line with the principle of the id.

\section{References}

Abrams, M H. (1999). A Glossary of Literary Terms. Earl Mcpeek.

Colbert, David. (2006). The Magical Worlds of Harry Potter (Terj). Jakarta: PT. Gramedia Pustaka Utama.

Fudyartanta, KI. (2012). Psikologi Kepribadian: Paradigma Filosofis, Tipologis, Psikodinamik dan Organismik-Holistik. Yogyakarta: Pustaka Pelajar.

Hanimasari, Elyla. (2010). A Psychological Approach in Obsession of Main Character in Paulo Coeltio's Eleven Minutes. (unpublished thesis). Surabaya:Universitas Muhammadiyah Surabaya.

Hasmiati, Rahmatullah Ayu. (2012). A Psycholytic Study of Constance Chatterley's Love in R.H Lawrence;s Lady Chatterley's Lover. (unpublished thesis). Surabaya: Universitas Muhammadiyah Surabaya.

Kennedy, X J and Dana Gioia. (2007). Literature: An Introduction to Fiction, Poetry, and Drama. Longman.

Miles, Matthew B and A Michael Huberman. (1992). Analis Data Kualitatif (Terj). Tjetjep Rohendi Rohidi. Jakarta: Penerbit Univeristas Indonesia.

Minderop, Albertine. (2010). Psikologi Sastra: Karya Sastra, Matode, Teori, dan Contoh Kasus. Jakarta: Yayasan Pustaka Obor Indonesia.

Potter, James L. (1967). Elements of Literature. New York: The Odyssey Press Inc.

Rowling, J K. (2005). Harry Potter and the Half-Blood Prince. USA

Strauss, Anselm, and Juliet Corbin. (2007). Dasar-Dasar Penelitian Kualitatif Prosedur, Teknis, dan Teori Grounded (Terj). Djunaidi Ghony, H.M. Surabaya: PT. Bina Ilmu Offset. 